\title{
EU makes three moves to boost biotech
}

OXFORD_-Europe's bioscience community has started 1994 in a better position than it may have anticipated, following three 1993 year-end moves by the European Union (EU, Brussels). The EU's Council of Ministers (CoM), which contains a ministerial representative from each of the EU's 12 member countries, rejected a proposal from the EU's European Commission (EC), the EU's civil service, for a seven-year ban on the sale of bovine somatotropin (BST). Also, European trade ministers, sitting in the EU's Internal Market Council (IMC), have drafted a proposal on new patent rules to protect biotechnological inventions in Europe. And, finally, officials at the EC amended a proposal to regulate novel foods and novel food ingredients that contain genetically modified components.

The CoM first prohibited BST sales within the EU in April 1990 to allow the EC to gather more evidence relating to the safety and efficacy of the product. The EC then persuaded the CoM to extend the BST moratorium to December 31,1993 , so that it could gather all the BST data it needed. Yet recently the EC told the CoM that it was unable to complete its BST study by the end of last year and that it wanted more time to evaluate the product. It was then that the EC proposed a seven-year moratorium on BST sales, a proposal that the CoM rejected. In a statement, the CoM noted that a "period of extension of one year can be usefully applied to continue to study the various implications of the eventual decision which must be taken and, notably, the consequences for international trade and the new situation created by the decision" of the U.S. to authorize the marketing of BST. The EC will now continue evaluating BST, while the CoM will allegedly decide sometime this year whether to approve, reject, or defer BST marketing.

Though the IMC's draft proposal on new patent rules to protect biotechnological inventions does not have the full backing of all EU member states-as Denmark, Spain, and Luxembourg have signaled their opposition-it is still seen as a step forward. Indeed, proposals from the EC to harmonize European rules on patents for living matter have been in the pipeline for six years now, with the debate focused on the ethical and economic implications of allowing such patents. The EC, in fact, proposed an amendment in 1992 that would bar patents for biotechnological inventions that are considered "contrary to public policy or morality" and that concern "parts of the human body per se." Though EU member states agree that the human body should not be patentable, some states disagree over whether human DNA sequences are patentable.

Perhaps the IMC draft proposal's most significant amendment is the reversal of burden of proof in patentinfringement cases. Currently, it is up to the patent holder to prove that an alleged infringer is guilty of unauthorized use of a patent. The draft proposal shifts that burden of proof onto the alleged infringer, who must now prove that he is not infringing the accuser's patents.
Yet the earliest that the IMC's draft proposal could go into effect is in the beginning of 1997, and then only under the rosiest of scenarios.

The ECalso unveiled amendments to its proposal to regulate novel foods and novel food ingredients containing genetically modified components. This proposal, too, has endured a tortured path through the labyrinthine EU regulatory system, with its number of versions now running into double figures. In this latest version, EC officials have taken on board the view that additional labeling requirements may be needed to ensure that consumers are aware of the differences between conventional foods and so-called novel foods and novel food ingredients. However, the EC shied away from calls to introduce a requirement to have technology-specific labeling of foods containing genetically modified components. EC officials believe that "such provisions tend to stigmatize, while providing little useful information to the consumer." - Mike Ward
In one move, the EU's

\section{Council of}

\section{Ministers}

rejected a

proposal for a

seven-year ban

on the sale of

BST.

\section{Waters BioDiscovery System: Discover a Macrocosm of Results in Microcosmic Analysis}

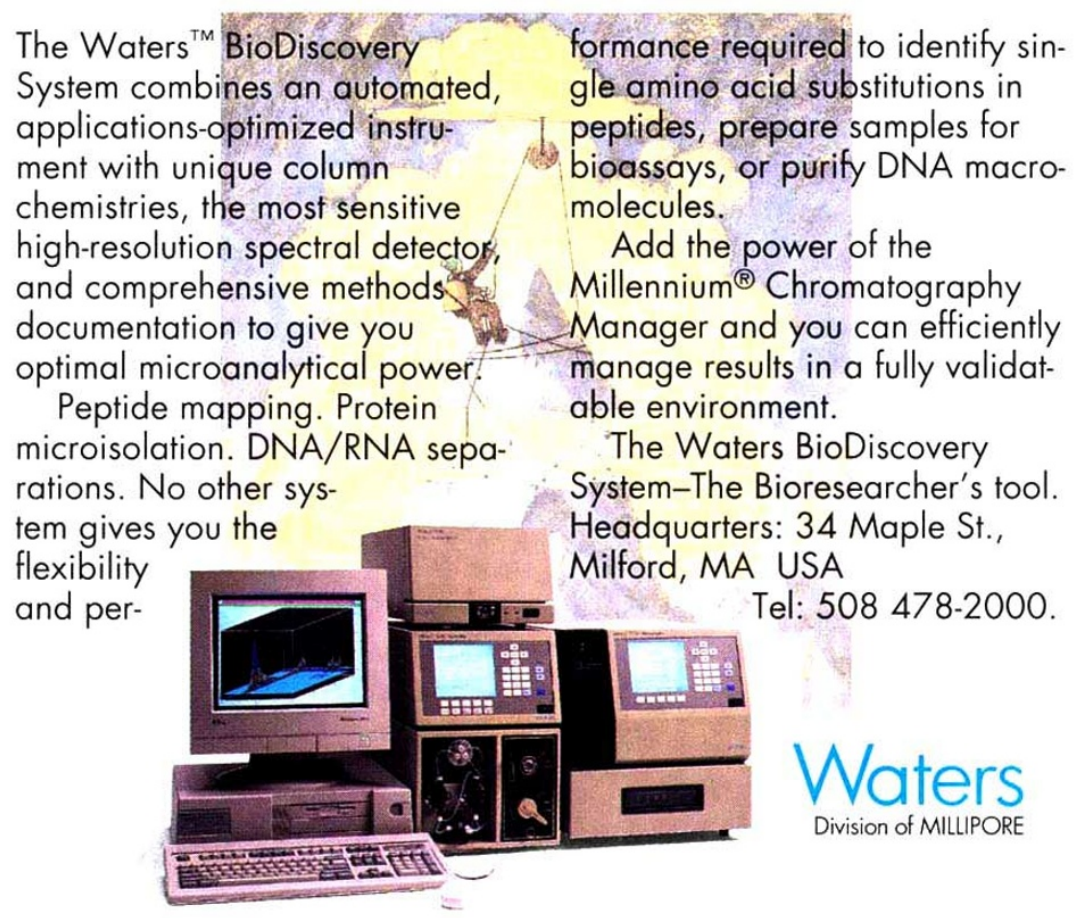

Write in No. 120 on Reader Service Card 